\title{
Małgorzata Lorencka
}

\section{Rola i znaczenie instytucji referendum we współczesnych Włoszech ${ }^{1}$}

Instytucja referendum została przyjęta we Włoszech po II wojnie światowej² Jej wprowadzanie wzbudziło szerokie dyskusje na temat funkcji, jaką ma spełniać ta forma demokracji bezpośredniej w systemie przedstawicielskim. Już podczas obrad Zgromadzenia Konstytucyjnego w 1946 r., w ramach tzw. Komisji Siedemdziesięciu Pięciu rozważano wykorzystanie referendum jako przeciwwagi wobec działań parlamentu, a także jako instrument służący do uchylania aktów ustawodawczych. „Komunistyczna i socjalistyczna lewica, wówczas atakowana za parlamentarny centryzm ideologiczny, patrzyła podejrzliwie na instytucję referendum, natomiast część katolików podkreślała naturę potencjalnej kontrwładzy wewnątrz nowej demokracji masowej ${ }^{3}$ W koncepcji jednego z ojców włoskiej konstytucji, Costantino Mortatiego, referendum stanowiło nie tylko ważne narzędzie w rozwiązywaniu konfliktów między rządem a parlamentem, ale nade wszystko instrument wyrażania woli obywateli". Co ciekawe, skutkiem dyskusji w Konstytuancie było ograniczenie roli referendum w przyszłym ustroju Włoch, szczególnie wobec oporu posłów partii komunistycznej. Z kolei po uchwaleniu konstytucji to właśnie przedstawiciele lewicy domagali się jak najszybszego przegłosowania ustawy o referendum i jego wykorzystania. W związku z zimnowojennym podziałem Europy rządząca chadecja zwlekała z uchwaleniem aktów wykonawczych do konstytucji, obawiając się instytucji referendum jako potencjalnego środka do antysystemowej

1 Artykuł jest zmodyfikowaną wersją referatu wygłoszonego na I Seminarium Młodych Badaczy Prawa Konstytucyjnego, które odbyło się w Mąchocicach Kapitulnych w dniach 11-12 marca $2010 \mathrm{r}$.

2 Trzeba zwrócić uwagę, że już proces zjednoczenia państwa włoskiego w drugiej połowie XIX wieku przebiegał przy zastosowaniu formy instytucji demokracji bezpośrednie, w postaci plebiscytu, referendum natomiast odgrywało znaczącą rolę w rozwoju włoskich społeczności lokalnych. Por. I. Bokszczanin, Referendum we Wtoszech, [w: ] E. Zieliński, I. Bokszczanin, J. Zieliński, Referendum w państwach Europy, Warszawa 2003, s. 347-348.

3 F. Lanchester, Le innovazione istituzionale forzata: il referendum abrogativo tra 'stimolo' e'rottura', [w: ] I referendum eletttorali. Seminario di studio e documantezione, pod redakcją F. Lanchester, Roma 1992, s. 16.

4 A. Chimenti, Storia del referendum, Roma 1993, s. 14-15. 
działalności komunistów. Powyższe okoliczności doprowadziły do zablokowania włoskiej demokracji i wprowadzenia z opóźnieniem szeregu instytucji przewidzianych w konstytucji, takich jak Trybunał Konstytucyjny, organy regionalne czy instytucje demokracji bezpośredniej ${ }^{5}$. A to właśnie referendum instytucjonalne z 2 czerwca 1946 r., poświęcone kwestii wyboru między monarchią a republiką, stało się fundamentem budowy powojennego państwa włoskiego ${ }^{6}$.

Konstytucja Włoch z 22 grudnia 1947 r. przewiduje dwie formy demokracji bezpośredniej: inicjatywę ludową oraz referendum7 Prawo inicjatywy ludowej, czyli zgłaszania projektów ustaw posiada grupa co najmniej 50 tys. obywateli. Z kolei odnośnie do referendum przewidziano trzy jego postacie:

- referendum abrogacyjne (uchylające) - na żądanie co najmniej 500 tys. wyborców albo pięciu rad regionalnych może odbyć się konsultacja w celu całkowitego lub częściowego uchylenia ustawy lub aktu o mocy ustawy. Niedopuszczalne jest referendum w sprawach podatkowych, budżetu, amnestii, abolicji oraz upoważnienia do ratyfikacji traktatów międzynarodowych. Dla ważności tego rodzaju referendum wymagane jest kworum 50\% wyborców plus jeden (art. 75 konstytucji Włoch);

- referendum konsultacyjne - może mieć miejsce w wypadkach odłączenia lub przyłączenia prowincji i gmin z jednego do drugiego regionu (art. 132 ust. 1) czy w innych kwestiach, które nie zostały bezpośrednio wyrażone w konstytucji. Frekwencja nie ma znaczenia dla ważności wyniku konsultacji;

- fakultatywne referendum konstytucyjne - ma ono charakter ratyfikacyjny, ponieważ w myśl art. 138 ust. 2 dotyczy ustaw o rewizji konstytucji oraz ustaw konstytucyjnych, które nie uzyskały aprobaty większości $2 / 3$ członków izb; są poddawane referendum, jeśli taki wniosek złoży $1 / 5$ członków jednej z izb parlamentu albo 500 tys. wyborców, albo pięć rad regionalnych $\mathrm{w}$ ciągu trzech miesięcy od ich publikacji. Także ten rodzaj referendum nie przewiduje kworum dla ważności rezultatu konsultacji.

We Włoszech, pomimo przepisu konstytucyjnego o instytucji referendum, faktyczna możliwość jego wykorzystania nastąpiła dopiero w latach 70., kiedy uchwalono ustawę nr 352 z 25 maja 1970 r. ${ }^{9}$ Referenda dotyczyły różnych kwestii spo-

5 J. Zakrzewska, Ustrój polityczny Republiki Włoskiej, s. 178-180.

6 Por. szerzej, J. Zakrzewska, Ustrój polityczny..., s. 25-26.

7 Konstytucja Republiki Wtoskiej, tłum. i wstęp Z. Witkowski, Warszawa 2004.

8 Por. Z. Witkowski, Ustrój konstytucyjny wspótczesnych Włoch $w$ aktualnej fazie jego przemian 1989-2004, Toruń 2004, s. 32.

9 Ustawa z 25 maja 1970 r., nr 352 o przewidzianym w konstytucji referendach oraz ludo- 
łecznych i politycznych. Najbardziej dyskutowane było referendum o rozwodach z 12 maja 1974 r., które wzbudziło szerokie zainteresowanie społeczne, frekwencja wyniosła bowiem $87,7 \%$ uprawnionych do głosowania. Przeciwko zniesieniu rozwodów opowiedziało się 59,3\% wyborców. Wiele emocji wzbudziło także referendum abrogacyjne z 17 maja 1981 r., przeprowadzone tuż po zamachu na Jana Pawła II. Pomimo apelu papieża aż $88,4 \%$ Włochów opowiedziało się za utrzymaniem prawa do przerywania ciąży. Na przełomie lat siedemdziesiątych i osiemdziesiątych odbyły się ważne referenda abrogacyjne w następujących kwestiach: przeciw zniesieniu finansowania partii politycznych przez państwo i zniesieniu kary dożywocia z 11 czerwca 1978 r., koncesji na broń z 1981 roku, odpowiedzialności cywilnej sędziów oraz konstrukcji elektrowni jądrowych, regulacji dotyczących polowań z 8 listopada $1987 \mathrm{r}$.

Cześć przedstawicieli włoskiej doktryny konstytucyjnej uważała, iż skutecznym instrumentem odblokowania systemu politycznego i wyjścia z jego kryzysu będzie zmiana prawa wyborczego. Ówczesna proporcjonalna ordynacja wyborcza do izb parlamentu była bowiem krytykowana za spowodowanie nadmiernej fragmentaryzacji partyjnej, a jednocześnie stanowiła silne oparcie dla „rządów partii”. Wobec bezskutecznych prób reformy drogą parlamentarną, zdecydowano się na wykorzystanie innego środka, jakim było referendum abrogacyjne (uchylające) w myśl art. 75 konstytucji ${ }^{10}$.

Jednym z pierwszych zwolenników reformy wyborczej był przywódca radykałów Marco Pannella, który w 1986 r. proponował wprowadzenie systemu większościowego na wzór brytyjski ${ }^{11}$. W następnym roku powstał Ruch na rzecz reformy

wej inicjatywie ustawodawczej - Legge del 25 maggio 1970, n. 352 - Norme sui referendum previsti dalla Costituzione e Sulla iniziativa legislativa del popolo, „Gazzatta Ufficiale della Repubblica Italiana”, n. 147 del 15 giugnio 1970.

10 Od chwili uchwalenie ustawy wykonawczej do art. 75 konstytucji Włoch o referendum abrogacyjnym (legge 25 maggio 1970, n. 352 - Norme sui referendum previsti dalla costituzione e sulla iniziativa legislativa del popolo - „Gazzetta Ufficiale della Repubblica Italiana” del 15 giugno 1970, n. 147) ten instrument demokracji był często wykorzystywany. W latach siedemdziesiątych zdecydowano w ten sposób o wprowadzeniu rozwodów czy później aborcji. W latach dziewięćdziesiątych konsultacje referendalne odbyły się w latach: 1991, 1993, 1995, 1997, 1999, 2000, obejmując szeroką problematykę społeczno-polityczną. Por. szerzej Referendum. Problemi teorici ed esperienze costituzionali, pod red. M. Luciani, M. Volpi, Roma-Bari 1992; I. Bokszczanin, Referendum we Wtoszech, [w: ] Referendum w państwach Europy, pod red. E. Zielińskiego, I. Bokszczanin, J. Zielińskiego, Warszawa 2003, s. 347-388; I. Bokszczanin, Reforma instytucji politycznych Republiki włoskiej w latach dziewięćdziesiątych XX wieku, Warszawa 2004, s. 57-96.

11 26-27 września 1986 r. Marco Pannella założył Ligę na rzecz okręgu jednomandatowego 
wyborczej (Movimento per la riforma elettorale) chadeckiego polityka Mario Segniego, który popierał model francuski w wyborach do Zgromadzenia Narodowego (jednomandatowe okręgi z głosowaniem w dwóch turach) ${ }^{12}$. Powyższe inicjatywy nie miały jednak szans realizacji ze względu na sprzeciw partii rządzących, chcących zachować status quo.

Zmiany polityczne na przełomie lat osiemdziesiątych i dziewięćdziesiątych przyczynily się do powstania szerokiego ruchu reformatorskiego. Zwolennikami wprowadzenia sytemu większościowego byli m.in.: część katolickich intelektualistów (np. Pietro Scoppola, Arturo Parisi), część polityków postkomunistycznych z Demokratycznej Partii Lewicy, radykałowie M. Pannelli i część chadeków na czele z M. Segni. Impulsem do działania było uchwalenie przez parlament nowej ustawy o samorządzie terytorialnym (ustawa $\mathrm{nr} 142$ z 1990 r.). Wprawdzie propozycja bezpośrednich wyborów burmistrzów nie została przyjęta, jednak zmusiła ona ruch do szukania innego sposobu przeprowadzenia reformy wyborczej. Tak powstał 6 kwietnia 1990 roku Komitet na rzecz referendum wyborczego (Comitato per il referendum elettorale - tzw. COREL). Jego przewodniczącym został Mario Segni, zastępcą Augusto Barbera. Ruch wykorzystał ideę Serio Galeottiego o przeprowadzeniu referendum abrogacyjnego odnośnie do systemu wyborczego do Senatu z 1988 r. ${ }^{13}$. Po konsultacjach zdecydowano się złożyć trzy wnioski do poddania pod referendum: uchylenie części ordynacji wyborczej do Senatu na rzecz wprowadzenia systemu większości względnej, zmianę ordynacji do Izby Deputowanych - uchylenie wielokrotnej preferencji i pozostawienie tylko jednej oraz zmiany ordynacji wyborczej do władz lokalnych, proponując uchylenie różnic między gminami poniżej 5 tys. mieszkańców i gminami powyżej tej liczby, a także zniesienie systemu panachag' $\mathbf{u}^{14}$.

Zebrano ponad 608 tys. podpisów pod wnioskami o przeprowadzenie referendum, a następnie złożono je w Sądzie Kasacyjnym. Postanowieniem Trybunału Konstytucyjnego dopuszczono do głosowania tylko jeden wniosek - o uchylenie wielokrotnej preferencji w wyborach do Izby Deputowanych ${ }^{15}$. Termin konsultacji

(La Lega per il collegio uninominale). Por. P. Scoppola, La repubblica dei partiti. Evoluzione e crisi di un sistema politico 1945-1996, Bologna 1997, s. 473; A. Barbera, A. Morrone, La Repubblica dei referendum, s. 154.

12 Por. A. Barbera, A. Morrone, La Repubblica dei..., s.154.

13 Tamże, s. 119.

14 Por. G. Pasquino, La promozione dei referendum elettorali, „Politica in Italia. I fatti dell'anno e le interpretazioni. Edizione 91", Bologna 1991, s. 49-51.

15 Postanowienie nr 47 Trybunału Konstytucyjnego z 2 lutego $1991 \mathrm{r}$. 
wyznaczono na 9 i 10 czerwca 1991 r. Ówczesne elity polityczne, zagrożone utratą swej pozycji, nawoływały do powstrzymania się od głosu, co najlepiej wyrażały słowa sekretarza socjalistów Bettino Craxiego - „pójdźcie nad morze” (andate al mare). Jednak Włosi stawili się do urn wyborczych, zagłosowało bowiem 62,5\% uprawnionych, z czego 95,6\% poparło wniosek promotorów referendum. Była to więc porażka obozu rządzącego, a jednocześnie znak sprzeciwu społeczeństwa wobec dotychczasowej polityki.

Poparcie społeczne dla ruchu reformatorskiego skłoniło jego przywódców do ponownego złożenia wniosków o uchylenie przepisów w ordynacjach do Senatu i władz lokalnych. W tym samym czasie jednak parlament powołał drugą Dwuizbową Komisję do spraw Reform Instytucjonalnych, by osłabić siłę inicjatywy referendalnej. W jej skład powołano Augusto Barberę i po początkowym wykluczeniu także Mario Segniego. Rządzący chadecy i socjaliści byli zdecydowani uprzedzić głosowanie nad wnioskami referendalnymi, przyspieszając pracę parlamentu nad zmianami w prawie wyborczym. Efektem tej strategii było uchwalenie nowej 25 marca 1993 r. ordynacji do władz lokalnych o bezpośrednim wyborze burmistrzów i przewodniczących prowincji ${ }^{16}$. Tym samym wniosek o referendum w tej sprawie stał się zbędny. Również odnośnie do drugiego wniosku referendalnego parlament uchwalił zmianę prawa wyborczego do Senatu. Przyjęta 16 stycznia 1992 r. ustawa zmieniała jednak tylko nieznacznie zapisy ordynacji, m.in. wprowadzając formułę, że „przewodniczący Okręgowego Biura Wyborczego ogłasza wybranym kandydata, który otrzymał największą liczbę głosów ważnych, nie mniejszą niż $65 \%$ wszystkich głosów ważnych w okręgu" ${ }^{17}$. Tymczasem promotorzy referendum złożyli wymaganą liczbę podpisów dwa dni wcześniej (ponad 1300000 podpisów) ${ }^{18}$. W związku z tym, że parlament zmienił ordynację do Senatu, musiał zostać przeformułowany wniosek o referendum. Znacznie ułatwiło to czytelność wniosku, proponującego zapis, iż „przewodniczący Okręgowego Biura

16 Por. Legge 25 marzo 1993, n. 81 - Elezione diretta del sindaco, del presidente della provincia, del consiglio comunale e del consiglio provinciale, "Gazzetta Ufficiale della Repubblica Italiana” del 27 marzo 1993, n. 72. Należy również zauważyć, że we Włoszech stosuje się słowo „sindaco” jako odpowiednik polskiego wójta, burmistrza i prezydenta miasta. Por. także M. Rakowski, Prawo wyborcze do włoskiej Izby Deputowanych w latach 1861-1923, Warszawa 2004, s. 12-13.

17 Poprzedni zapis brzmiał: „przewodniczący Okręgowego Biura Wyborczego ogłasza wybranym kandydata, który otrzymał liczbę głosów ważnych nie mniejszą niż $65 \%$ wszystkich głosów ważnych w okręgu" (art. 19 ordynacji do Senatu).

18 P. Corbetta, A. M. L. Parisi, Ancora un 18 aprile. Il referendum sulla legge elettorale per il Senato, „Politica in Italia. I fatti dell'anno e le interpretazioni. Edizione 94”, Bologna 1994, s. 144. 
Wyborczego ogłasza wybranym kandydata, który otrzymał największą liczbę głosów ważnych w okręgu”.

Drugie już referendum wyborcze odbyło się 18 i 19 kwietnia 1993 r. Obok zmiany w ordynacji senackiej dołączono jeszcze siedem innych kwestii19. W głosowaniu wzięło udział $77 \%$ uprawnionych, z czego za proponowaną zmianą opowiedziało się 82,7\% głosujących. Przyjmując wolę obywateli wyrażoną w referendum, parlament uchwalił nowe ordynacje wyborcze 4 sierpnia $1993 \mathrm{r} .{ }^{20} \mathrm{Na}$ ich podstawie $75 \%$ członków każdej z izb wybiera się w jednomandatowych okręgach wyborczych większością zwykłą głosów, a pozostałe $25 \%$ miejsc rozdziela się według formuly proporcjonalnej ${ }^{21}$. Pierwsze wybory parlamentarne na podstawie nowych zasad zostały przeprowadzone 27-28 marca $1994 \mathrm{r}$.

Dopełnieniem zmian ustawodawstwa wyborczego było przyjęcie nowej ustawy o wyborze rad regionalnych w regionach o statucie zwykłym z 23 lutego 1995 r. $^{22}$ Przyjęto system mieszany, gdyż $80 \%$ miejsc w radzie regionalnej było rozdzielonych według formuly proporcjonalnej między listy prowincjonalne, a pozostałe $20 \%$ otrzymywała lista regionalna, która uzyskała najwięcej głosów. Tak więc w I połowie lat dziewięćdziesiątych wprowadzono siedem różnych odmian systemu mieszanego na wszystkich szczeblach władzy ${ }^{23}$. Taka formuła była kompromisem wobec powojennego układu politycznego i samych partii politycznych, pozostawiając również proporcjonalny rozdział mandatów.

Mario Segni tak ocenił sukces w referendum z 1993 r.: „Nadzwyczajne zwycięstwo (...), zwycięstwo całego ludu włoskiego, który olbrzymią większością ustanowił fundamenty nowej Republiki, Republiki obywateli”. Z kolei kongres Włoskiego Stowarzyszenia Konstytucjonalistów określił referendum „metaforą władzy

19 Pozostałe 7 wniosków o referendum dotyczyło: finansowania partii politycznych ze środków publicznych, likwidacji Ministerstwa Rolnictwa, Ministerstwa Turystyki oraz Ministerstwa Udziałów Państwowych, partyjnych nominacji w Kasach Oszczędnościowych, kompetencji gminy w dziedzinie ochrony środowiska oraz zniesienia kar za posiadanie narkotyków na użytek osobisty. Szerzej I. Bokszczanin, Reforma instytucji politycznych..., s. 74-75.

20 Por. Legge 4 agosto 1993, n. 276 - Norme per l'elezione del Senato della Repubblica, „Gazzetta Ufficiale della repubblica Italiana” del 6 agosto 1993, n. 77; Legge 4 agosto 1993, n. 277 - Nuove norme per l'elezione della Camera dei Deputati, „Gazzetta Ufficiale della Repubblica Italiana” del 6 agosto 1993, n. 183.

21 Szerzej na temat konstrukcji prawnej ordynacji wyborczej do izb parlamentu włoskiego oraz różniących je rozwiązaniach napisano w rozdziale IV pracy.

22 Legge 23 febbraio 1995, n. 43 - Nuove norme per la elezione dei consigli delle regioni a statuto ordinario, "Gazzetta Ufficiale della Repubblica Italiana” del 24 febbraio 1995, n. 46.

23 Por. R. D’Alimonte, La transizione italiana: il voto regionale del 23 aprile, „Rivista italiana di scienza ppolitica” nr 3, 1995, s. 524. 
uchwałodawczej” (potere costituente) ${ }^{24}$. W moim przekonaniu należy również zaznaczyć, że mimo pozytywnych rezultatów referendów wyborczych czy referendum w sprawie uchylenia publicznego finansowania partii politycznych z 1993 r., nie zrealizowano w pełni woli wyborców. Na pewno należy jednak docenić innowacyjny charakter samych referendów i jego wplyw na transformację powojennego systemu politycznego Włoch.

Powstały w 1995 r. rząd Lamberto Diniego, tworzony przez bezpartyjnych specjalistów, działał w okresie przejściowym, który był niezbędny dla konsolidacji sił politycznych. W miejsce poprzednich trzech bloków politycznych powstały dwie koalicje: centrolewicowa o nazwie Drzewo Oliwne (Ulivo) oraz centroprawicowa Biegun Wolności (Polo delle Libertà). Był to trudny okres zwłaszcza dla Silvio Berlusconiego, objętego dochodzeniem mediolańskiej prokuratury oraz odejściem Ligii Północnej z koalicji, stąd też przyjęto określać ten etap mianem „przejścia przez pustynię” (traversata del deserto) ${ }^{25}$. Przeprowadzone 11 czerwca 1995 roku referenda były testem akceptacji dla posiadanych przez Berlusconiego prywatnych stacji telewizyjnych ${ }^{26}$. Impas instytucjonalny z 1995 r. był przyczyną nasilających się żądań rozwiązania parlamentu i przeprowadzenia przedterminowych wyborów. Główne ugrupowania polityczne podkreślały tworzenie się nowego „ducha” polityki, wobec czego koniecznością stało się dostosowanie do niego zapisów konstytucyjnych.

21 kwietnia 1996 r. odbyły się wybory parlamentarne. Przyniosły one zwycięstwo koalicji centrolewicowej Drzewa Oliwnego na czele z Romano Prodim, który wkrótce utworzył swój rząd. Po raz pierwszy w powojennej historii Włoch zasiedli w nim postkomuniści z Demokratycznej Partii Lewicy, zrywając tym samym z powojenną polityką ich izolacji - conventio ad excludendum. Podobnie jednak jak w 1994 r. rząd miał tylko większość absolutną w jednej izbie parlamentu - Senacie, w Izbie Deputowanych natomiast musiał zabiegać o wsparcie ze strony Odbudowy Komunistycznej. To najbardziej lewicowe ugrupowanie stało się źródłem późniejszych problemów rządzącej koalicji, doprowadzając do upadku rządu Prodiego i powstania kolejnych niestabilnych gabinetów. Mimo tych trudności koalicja centrolewicowa rządziła do końca kadencji izb w 2001 r. Do jej osiągnięć należy zaliczyć: poprawę sytuacji ekonomicznej państwa, proces prywatyzacji sektora publicznego, wejście Włoch do strefy euro już od 1 stycznia $1999 \mathrm{r}$. W sferze reform ustrojowych najpierw podjęto

24 Por. A. Barbera, A. Morrone, La Repubblica dei..., s. 138.

25 Por. http://www.forza-italia.it/silvioberlusconi/08_deserto.htm (25.08.2005).

26 Szerzej: A. Barbera, A. Morrone, La Repubblica dei..., s. 171-188. 
współpracę z opozycją w ramach trzeciej już Dwuizbowej Komisji Parlamentarnej ds. Reform Konstytucyjnych. Porażka tejże spowodowała powolny proces reform, szczególnie w wymiarze sprawiedliwości i administracji publicznej. Ich efektem była również reforma konstytucyjna tytułu V ustawy zasadniczej, odnosząca się do regionalnej struktury państwa w latach 1999-2001.

W drugiej połowie lat dziewięćdziesiątych należy również zwrócić uwagę na proces ewolucji stanowiska Ligii Północnej. Po wyjściu z koalicji centroprawicowej Silvio Berlusconiego partia obrała drogę samodzielnej polityki, obawiając się utraty swej pozycji w północnej części kraju na rzecz Forza Italia. Przywódca Ligii Umberto Bossi zastąpił wcześniejszą propozycję utworzenia państwa federalnego żądaniem odłączenia północnych obszarów Włoch (secesji) i powstania niezależnego państwa - Padanii. 25 marca 1996 r. uchwalono w Pontida tzw. Konstytucję Północy (La Constituzione del Nord). Następnie 5 maja zaprzysiężono w Mantui północny parlament, a Bossi ogłosił proklamację secesji na 15 września $1996 \mathrm{r}$. Wobec braku większych sukcesów 25 maja 1997 r. Liga zorganizowała na obszarze północnych Włoch referendum na temat secesji. Małe zainteresowanie tą tematyką doprowadziło do zmiany stanowiska partii i powrotu do idei federalnej formy państwa włoskiego. Stopniowo również nastąpił proces powrotu ugrupowania U. Bossiego do współtworzenia koalicji centroprawicowej S. Berlusconiego w $2001 \mathrm{r}$.

Podobnie jak w pierwszej połowie lat dziewięćdziesiątych, instrumentem pobudzenia zmian w państwie miało być referendum. Po 1995 r. kolejna grupa wniosków referendalnych została poddana pod głosowanie 15 czerwca 1997 r. ${ }^{27}$ Była to jednak porażka instytucji referendum, ponieważ w konsultacji wzięło udział 30,2\% uprawnionych, co stanowiło najniższą frekwencję w historii tej formy demokracji bezpośredniej we Włoszech. Mimo to ponownie sięgnięto po referendum odnośnie do zmian w prawie wyborczym do obu izb parlamentu, nie powiodly się bowiem próby ich wprowadzenia drogą parlamentarną. 18 kwietnia 1999 r. głosowano nad wnioskiem o zniesienie podziału proporcjonalnego w wyborach do Izby Deputowanych. Frekwencja wyniosła 49,6\% uprawnionych wyborców, w tym za zmianą opowiedziało się 91,7\% głosujących. Brak wymaganego kworum większości bezwzględnej spowodował ponowne przeprowadzenie referendum w tej kwe-

27 Pod głosowanie w referendum z 15 czerwca 1997 r. zostały poddane następujące kwestie: prywatyzacja, zastępcza służba wojskowa, polowania, awansowanie sędziów, prawo prasowe, dodatkowe zatrudnienie sędziów, likwidacja Ministerstwa Polityki Rolnej. Por. I. Bokszczanin, Reforma instytucji politycznych..., s. 82; A. Barbera, A. Morzone, La Repubblica dei..., s. 202-205; M. Donovan, I referendum del 1997: il troppo stroppia?, „Politica in Italia. I fatti dell'anno e le interpretazioni. Edizione 98”, pod red. L. Bardi, M. Rhodes, s. 197-217. 
stii 21 maja 2000 r. Jednak tym razem frekwencja była o wiele niższa, wyniosła bowiem $32,4 \%$ uprawnionych do głosowania ${ }^{28}$. Jedyną zmianą w prawie wyborczym była nowelizacja art. 48 konstytucji, dotycząca „utworzenia okręgu zagranicznego do wykonywania prawa głosowania przez obywateli włoskich zamieszkałych zagranicą" (ustawa konstytucyjna nr 1 z 23 stycznia 2001 r.). Wcześniejsze niepowodzenia abrogacyjnych (uchylających) referendów w myśl art. 75 konstytucji nie stanowily jednak przeszkody dla przeprowadzenia po raz pierwszy w historii Włoch referendum konstytucyjnego w myśl art. 138 konstytucji. Przeprowadzono je 7 października 2001 r., zatwierdzając uchwaloną przez parlament zmianę tytułu V konstytucji odnośnie do formy państwa ${ }^{29}$.

Choć nie bez wpływu na charakter działań elit politycznych były żądania secesji ze strony Ligi Pólnocnej czy przeprowadzane referenda, promowane głównie przez radykałów, to jednak największe znaczenie miała współpraca międzykoalicyjna (centroprawica-centrolewica). Podjęto ją w celu realizacji reformy struktury organów władz państwowych, najpierw w Dwuizbowej Komisji Parlamentarnej ds. Reform Konstytucyjnych pod przewodnictwem Massimo D’Alemy w latach 1997-1998, a później kontynuowano tę wspólpracę przy wyborze już w pierwszej turze Prezydenta Republiki Carlo Azeglio Ciampiego (13 maj 1999 r.) czy przy uchwaleniu przepisów konstytucyjnych dotyczących wyboru bezpośredniego Przewodniczącego Giunty Regionu i autonomii statutowej regionów (ustawa konstytucyjna $\mathrm{nr} 1$ z 22 listopada 1999 r.). Był to zwrot w polityce włoskiej, dotychczas opartej na wzajemnej delegitymizacji na linii continuum lewica-prawica. Choć później kontynuowano jednostronną politykę koalicyjną, stopniowo zmieniając fundamenty systemu politycznego, to jednak nie udało się przeprowadzić głębokiej reformy organizacji władz państwowych. Tylko kompromis polityczny bowiem jest w stanie wygenerować głębokie przemiany, dlatego w dalszej części zostanie przedstawiona próba tworzenia takiegoż kompromisu.

Także na poziomie regionalnym instytucje demokracji bezpośredniej spełniają znaczące funkcje. W statutach regionalnych zawarte zostały następujące formy demokracji bezpośredniej: konsultacje ludowe, konsultacje, prawo składania petycji, inicjatywa ludowa oraz trzy rodzaje referendów - abrogacyjne (w polskiej doktrynie prawa konstytucyjnego określane jako veto ludowe), konsultacyjne oraz fakultatywne referendum ratyfikacyjne.

28 Por. A. Barbera, A. Morzone, La Repubblica dei..., s. 221-224.

29 Tamże, s. 225-227. Za wnioskiem głosowało 64,2\% uprawnionych do głosowania obywateli. 
Instytucję konsultacji ludowej przewiduje na przykład statut regionu Molise z 1971 r. W art. 46 określa, że może ona mieć miejsce w odniesieniu do wybranej kategorii obywateli i dotyczyć interesującego ich postanowienia. Co więcej, może być skierowana do młodych ludzi, którzy jeszcze nie posiadają czynnego prawa wyborczego, ale ukończyli 16. rok życia, tym samym z definicji stając się pojęciem węższym od referendum konsultacyjnego, które dotyczy mieszkańców całego regionu lub jego części w odniesieniu do wybranej kwestii czy interesu (art. 45). $\mathrm{Z}$ tego względu wydaje się być nie zawsze uzasadnione twierdzenie B. Banaszaka, że we Włoszech konsultację ludową „określa się mianem referendum konsultacyjnego", choć w dużej mierze są to pojęcia tożsame ${ }^{30}$.

W celu wykonywania swych funkcji władze regionalne odbywają szerokie konsultacje z gminami i prowincjami, związkami zawodowymi, stowarzyszeniami i organizacjami społecznymi, instytucjami kulturalnymi. Mogą w tym celu prowadzić badania, spotkania i konferencje (np. art. 48 statutu Kampanii).

Prawo do składania petycji mają wszyscy obywatele regionu, rady gminne i prowincjonalne oraz inne podmioty, aby wskazać i żądać uregulowania niezbędnych spraw, istotnych dla życia społeczności lokalnej (art. 33 statutu Marche z $1971 \mathrm{r}$. czy art. 35 statutu regionu Lazio z 1971 r.).

Inicjatywa ludowa natomiast nie była do tej pory częstym przedmiotem przepisów statutowych. Bodaj najciekawszą i najbardziej rozbudowaną jej konstrukcje zawiera aktualny jeszcze statut Lombardii z $1971 \mathrm{r}$. Propozycje ustaw i przepisów regionalnych czy uchwał może złożyć grupa co najmniej 5 tys. wyborców regionu, rada prowincjonalna, co najmniej pięć rad gminnych albo tylko jedna lub więcej rad gminnych, zamieszkałych przez przynajmniej 25 tys. wyborców. Występuje jednak negatywny zakres rzeczowy materii stanowiących źródło inicjatywy ludowej. Do nich zalicza się sprawy podatkowe i budżetowe, kwestie wywłaszczenia ziemi, ograniczenia własności ziemskiej oraz obecnie uchylone nowelizacją konstytucji zmiany w statucie. O dopuszczalności danej materii decyduje prezydium rady regionalnej jednomyślnie, a w wypadku jej braku sama rada.

Rozpowszechnioną instytucją jest natomiast forma referendum regionalnego, mająca swe umocowanie prawne w ustawie ramowej nr 352 z $1970 \mathrm{r}^{31} \mathrm{~W}$ statutach przewidziano referendum abrogacyjne oraz referendum konsultacyjne. Wydaje się,

30 Por. B. Banaszak, Porównawcze prawo konstytucyjne współczesnych państw demokratycznych, Kraków 2004, s. 321.

31 B. Guerini, I modelli di referendum statale come limite ai referendum regionali, „Giurisprudenza costutuzionale" nr 1, 1978, s. 820-855. 
że sama instytucja przeżywa swój rozkwit. Referendum abrogacyjne przeprowadza się w celu uchylenia ustawy regionalnej lub jej części, przepisu albo postanowienia administracyjnego o charakterze ogólnym. Propozycje może składać określona grupa wyborców regionu (np. w Lazio na wniosek 50 tys. wyborców, w Lombardii 90 tys. wyborców, w Marche 20 tys. wyborców czy w Molise 10 tys.), dwie lub trzy rady prowincji oraz określona grupa rad gminnych. O dopuszczalności wybranej propozycji stanowi prezydium rady regionalnej, zastrzegając jednocześnie, że jego przedmiotem nie mogą być m.in. materie podatkowe oraz zatwierdzenie budżetu. Aby referendum było ważne, musi w nim wziąć udział większość uprawnionych do głosowania oraz opowiedzieć się za daną kwestią absolutna większość wyborców, którzy oddali głosy ważne. $\mathrm{W}$ przypadku negatywnego rezultatu ponowne referendum w tej sprawie może się odbyć zazwyczaj po upływie co najmniej roku (np. art. 39 statutu Lazio czy art. 44 statutu Molise, w Marche musi minąć pięć lat i nie mogą się odbyć więcej niż dwa referenda abrogacyjne w roku - art. 44 statutu z 1971 r.). Przykładowo referendum abrogacyjne z 11 maja 2003 r. na Sardynii uchyliło ustawy regionalne powołujące cztery nowe prowincje ${ }^{32}$.

Referendum konsultacyjne ustanawia się w stosunku do spraw interesujących wybraną ludność albo kwestii istotnych dla wszystkich wyborców regionu ${ }^{33}$. Zazwyczaj taka uchwała rady regionalnej musi uzyskać poparcie absolutnej większości radnych. Wśród wielu materii podległych temu typowi konsultacji wyróżnia się propozycja ustanowienia nowych gmin, zmian ich okręgów czy nazw. Interesujący przykład stanowi uchwała rady regionalnej Lombardii z 15 września 2000 r. odnosząca się do „propozycji uchwalenia referendum konsultacyjnego w sprawie przeniesienia funkcji państwowych w materii zdrowia, oświaty i policji lokalnej do kompetencji regionu”. Rząd zwrócił się do Trybunału Konstytucyjnego o zawieszenie uchwały, trwał bowiem proces deliberacji noweli konstytucyjnej odnoszącej się do wyżej wymienionych kwestii. Wniosek rządowy został oddalony, ale sama deliberacja lombardzka stanowiła nacisk na przyspieszenie prac nad reformą konstytucyjną, uchwaloną przez parlament przed orzeczeniem Trybunału.

Fakultatywne referendum ratyfikacyjne jest nowym rozwiązaniem w systemie regionalnym ${ }^{34}$. Swoje umocowanie prawne czerpie z art. 123 ust. 2 i 3 Konstytucji Republiki Włoskiej. Wprowadzona w 2001 r. norma określa przeprowadzenie ta-

32 Por. www.regione.sardegna.it/referendum2003/quesiti ref.html (11.03.2010).

33 Zob. szerzej: M. Scudiero, Il referendum regionale, [w:] Referendum. Problemi teorici ed esperienze costutizionali, pod red. M. Luciani i M. Volpi, Roma-Bari 1992, s. 145-149.

34 W konstytucji ustawodawca używa określenie „referendum ludowe” (referendum popolare). 
kiego referendum w sytuacji, gdy statut regionu lub jego zmiana nie uzyska akceptacji bezwzględnej większości członków rady regionalnej w dwóch kolejnych deliberacjach w ciągu co najmniej dwóch miesięcy. Referendum może się odbyć, jeśli w ciągu trzech miesięcy od jego publikacji zażąda tego 1/50 wyborców regionu lub 1/5 radnych. Statut musi uzyskać większość ważnie oddanych głosów. Przykładem wykorzystania tej instytucji jest region Friuli-Wenecja Julijska. 29 września 2002 r. odbyło tam się referendum w sprawie zmiany niektórych przepisów statutu, m.in. dotyczącej formy parlamentarno-zgromadzeniowej rządu ${ }^{35}$. Przy niskiej frekwencji $(23,06 \%)$ przeciwko tej ustawie statutowej opowiedziało się 73,06\%, w związku z czym ustawa nie mogła być promulgowana ${ }^{36}$.

Gianfranco Pasquino proponował już w latach osiemdziesiątych zmianę prawa wyborczego, która odblokowałaby system polityczny i skostniały układ partyjny ${ }^{37}$. Kolejne dziesięciolecie tylko w sposób częściowy potwierdziło tę tezę. Przekształcono wprawdzie ordynacje wyborcze $\mathrm{z}$ formuly proporcjonalnej na system mieszany (większościowo-proporcjonalny) w różnych jego odmianach w zależności od szczebla władzy, lecz nie przyniosło to upragnionej dla Włochów stabilizacji sytemu politycznego. Pomimo powstania bipolarnej rywalizacji politycznej nadal niezwykle trudno jest przeprowadzić rewizję konstytucji. Nie udało się zbudować szerokiego kompromisu politycznego, jaki miał miejsce w 1947 r. czy chociażby nawiązać do tzw. historycznego kompromisu z połowy lat siedemdziesiątych. Ten brak instytucjonalnego kompromisu powoduje powolny i stopniowy proces $z$ zmian $^{38}$. Indolencja elit politycznych i trudności w reformowaniu państwa przyczyniły się do większej aktywności wyborców na początku lat dziewięćdziesiątych, często wzywanych do wyrażenia swej opinii poprzez instytucję referendum czy inne konsultacje, stąd też Włochy określano często mianem demokracji refe-

35 Wcześniej zmiany zostały zatwierdzone przez większość 2/3 radnych. Statut regionu Friuli-Wenecja Julijska również w tym wypadku przewiduje fakultatywne referendum ratyfikacyjne, jeśli w ciągu 3 miesięcy od publikacji taki wniosek podpisze 1/30 uprawnionych do głosowania. Por. A. Morrone, Può il Friuli-Venezia Giulia fare „marcia indietro” sulla forma di governo regionale?, http//web.unife.it/progetti/forumcostituzionale/contributi/statuti2.htm. (11.03.2010).

36 Szerzej Z. Witkowski, Ustrój konstytucyjny wspótczesnych Włoch..., s. 415.

37 Teza G. Pasquino miała postać formuły „oddać berło księciu” (restituire lo scettro al principe), przy czym księciem jest obywatel, głosujący w wyborach i wybierający przedstawicieli do parlamentu. Z tego też względu głosy wyborców powinny mieć wpływ na konstrukcję rządu, a nie stanowić efekt przetargów partyjnych. Por. P. Scoppola, La repubblica dei partiti. Evoluzione e crisi di un sistema politico 1945-1996, Bologna 1997, s. 430-431; G. Pasquino, Restituire lo scettro al Proncipe, Roma-Bari, 1985.

38 Por. G. Sartori, La dittatura del premier, „Corriere della Sera” z 15 marca 2005 roku. 
rendalnej czy plebiscytowej. U progu XXI wieku obserwujemy jednak znużenie wyborców zbyt częstym wzywaniem do urn wyborczych, co wyraża przykładowo brak wymaganego kworum w referendach abrogacyjnych z 1997, 1999, 2000, 2003, 2005 czy 2009 r.

\section{Summary}

\section{The role and importance of the institution of the referendum in contemporary Italy}

The institution of a nationwide referendum in postwar Italy is one of the key elements of the socio-political changes, particularly in the presence of the indolence of the political elite and the so-called process of "unfinished constitutional transition" after 1993. The Constitution of the Italian Republic of 1947 provides for three basic forms of the referendum: a law-repealing referendum, a facultative constitutional referendum and a consultative referendum. Since the enactment of the Law on the referendum and the legislative initiative of 25 May 1970, was conducted in Italy 62 law-repealing referendums, two facultative constitutional referendums, and one consultative referendum. The law-repealing referendums concern such important issues as the introduction of divorce, abortion, artificial insemination, the abolition of life imprisonment, the construction of nuclear power plants until the changes in the financing of political parties and changes in electoral laws for both houses of Parliament. In the constitutional referendum of 2001, the citizens approved the rebuilding of the regional structure of the state, in referendum of 2006 protested against the reform proposals presented by the authorities of a center-right government of Silvio Berlusconi. The only one consultative referendum concern approved the creation of the European Parliament. By reason of the importance of issues raised and the number carried out the referendum, especially in recent years, Italy is often referred to as "the republic of referendums". However, the sore point of this form of direct democracy is decreasing voter participation, which leads to the absence of a quorum thus void consultation in case of a law-repealing referendum. Since 1997, the last 25 law-repealing referendums did not reach the required quorum, which raises further questions about the future of this institution. 